\title{
Trump v. Hawaii: Government Statements, Immigration, and First Amendment Jurisprudence
}

\author{
Bridget Brazil*
}

\section{INTRODUCTION}

President Trump first proposed a "'total and complete shutdown' of the entry of Muslims to the United States" in 2015. ${ }^{1}$ Three years earlier, in 2012, a bakery in Colorado refused to bake a cake for a same-sex couple. ${ }^{2}$ Both of these events spurred controversial Supreme Court cases and, although at first glance the two seem entirely different, both cases involved claims that the government discriminated on the basis of religion. ${ }^{3}$ Despite being decided by the same Court in the same term, the two cases had different outcomes. One decided in favor of the government, and the other decided against the government. ${ }^{4}$

Both cases also involve statements by governmental officials as evidence of animus towards religion. ${ }^{5}$ In Masterpiece Cakeshop, Ltd. v. Colorado Civil Rights Commission, these statements were used by the Court to find animus, but in Trump v. Hawaii, the Court refused to consider the statements made by President Trump and other government

\footnotetext{
* Associate Attorney, Wagstaff \& Cartmell, LLP; J.D., 2019, University of Kansas School of Law; B.A. 2016, Tufts University. I would like to thank the staff of the editorial board of the Kansas Law Review, especially Joy Merklen and Diana Stanley, for their time and effort in editing this piece. I would also like to give a special thank you to my friends and family for their input and continued support.

1. Jenna Johnson, Trump Calls for 'Total and Complete Shutdown of Muslims Entering the United States, 'WASH. POST (Dec. 7, 2015, 7:12 PM), https://www.washingtonpost.com/news/postpolitics/wp/2015/12/07/donald-trump-calls-for-total-and-complete-shutdown-of-muslims-entering-th e-united-states/?utm_term=.07e4a0f4057d [https://perma.cc/GAD2-NP77]; see also Presidential Candidate Donald Trump Rally in Mount Pleasant, South Carolina (CSPAN television broadcast Dec. 7, 2015), https://www.c-span.org/video/?401762-1/presidential-candidate-donald-trump-rally-mountpleasant-south-carolina/ [https://perma.cc/9MQ7-VU5W] [hereinafter Presidential Candidate] (statement at 00:30:36 minute marker).

2. Masterpiece Cakeshop, Ltd. v. Colo. Civil Rights Comm'n, 138 S. Ct. 1719, 1720 (2018)

3. Id. at 1723-24; Trump v. Hawaii, 138 S. Ct. 2392, 2417 (2018); Josh Blackman, The Travel Bans, 2018 CATO SuP. CT. REV. 29, 56 (2018) (discussing Justice Sotomayor's view that both Trump and Masterpiece ask the same fundamental question of "whether a government actor exhibited tolerance and neutrality in reaching a decision.").

4. Masterpiece, 138 S. Ct. at 1732; Trump, 138 S. Ct. at 2423.

5. Masterpiece, 138 S. Ct. at 1729; Trump, 138 S. Ct. at 2417.
} 
officials. $^{6}$ This Note examines Trump v. Hawaii's analysis of the Establishment Clause claim at issue, and the disconnect between the two cases and the possible explanations for it. This Note argues that the case should have been analyzed under the Free Exercise Clause, as was the case in Masterpiece. Further, this Note argues that under both traditional Establishment and Free Exercise Clause analysis, the Trump Proclamation likely would not have been upheld.

This Note also argues that by implementing the strange analysis in Trump, the Court left an unnecessary loophole in First Amendment protections in the area of immigration and national security, a loophole it should not be afraid to close. Trump is an Establishment Clause case brought by United States citizens in the United States and should not be analyzed under some unique weak standard that allows the President to do whatever he wants. The unusual treatment of this case makes it unclear how much scrutiny the Court will apply to Establishment Clause cases involving immigration. Future cases relating to executive orders on immigration should instead invoke some form of heightened scrutiny. In cases such as these, the President's words matter. The President is the sole voice of the United States to the world, and just as the rest of the world and the citizens of the United States use these words to understand the motivation for the President's actions, so should the Court.

\section{BACKGROUND}

The First Amendment guarantees that "Congress shall make no law respecting an establishment of religion, or prohibiting the free exercise thereof." 7 Two lines of jurisprudence are especially important for the purpose of this Note: cases relating to the establishment of religion, and cases relating to the free exercise of religion. ${ }^{8}$ Each of these lines of cases have their own analytical framework. ${ }^{9}$ Section II.A of the Note discusses Establishment Clause claims, the Trump Proclamation, and the case arising out of it. It lays out the history of the Ban from its first version to

6. Masterpiece, 138 S. Ct. at 1731; see Trump, 138 S. Ct. at 2435 (Sotomayor, J., dissenting).

7. U.S. CONST. amend. I.

8. Carl H. Esbeck, The Establishment Clause as a Structural Restraint on Governmental Power, 84 IowA L. REV. 1, 97-98 (1998) ("As a structural restraint, the purpose of the Establishment Clause is not to safeguard individual religious rights. That is the role of the Free Exercise Clause, indeed its singular role. Even in archetypal no-establishment cases . . . the Court has applied the Establishment Clause not to relieve individual complainants of religious coercion or religious harm, but to keep in proper relationship two centers of authority: government and religion.”).

9. See generally Timothy E. Flanigan, Smith and Lemon: Carried About with Every Wind of Doctrine, 1994 PuB. InT. L. Rev. 75 (1994). See e.g. Lemon v. Kurtzman, 403 U.S. 602, 607-08 (1971); Emp’t Div. v. Smith, 494 U.S. 872, 872 (1990). 
the current one and emphasizes the critical statements by the Trump Administration. Section II.B takes a closer look at Free Exercise claims generally, the framework used to decide them, and the levels of scrutiny applied to laws that are accused of violating the First Amendment. It also looks at the traditional use of the rational basis test and strict scrutiny, and how government statements have played into the analysis in these cases. Lastly, it considers Masterpiece as a point of comparison to Trump.

\section{A. Establishment Clause Analysis}

Generally, courts analyze Establishment Clause cases using the test set out by the Court in Lemon v. Kurtzman. ${ }^{10}$ There, the Court considered the constitutionality of Rhode Island statutes that provided aid to religious schools. ${ }^{11}$ Ultimately, the Court used a three-prong test to decide that the statutes indeed violated the Establishment Clause. ${ }^{12}$ Under the Lemon test, a statute or other government action must (1) have a "secular legislative purpose," (2) have a "primary effect... [that] neither advances nor inhibits religion," and (3) not foster an "excessive government entanglement with religion." 13 The first prong requires that a government action have some secular purpose, but not necessarily that the purpose is "solely secular."14 However, the Court has noted that "[w]hile the Court is normally deferential to a State's articulation of a secular purpose, it is required that the statement of such purpose be sincere and not a sham." 15 Even if the purpose is considered secular, the second prong prohibits government action that has the effect of showing a preference for or a condemnation of any religion. ${ }^{16}$ The third prong then disallows government action that leads to excessive entanglement with religion, especially considering the character of the institution that benefits from the government action. ${ }^{17}$

10. Marcia S. Alembik, Note, The Future of the Lemon Test: A Sweeter Alternative for Establishment Clause Analysis, 40 GA. L. REV. 1171, 1173-74 (2006) (quoting Brett G. Scharffs, Do Displays of the Ten Commandments on Public Property Violate the Establishment Clause?, 2004-05 PREVIEW U.S. SUP. CT. CAS. 298, 305); see Gary J. Simson, The Establishment Clause in the Supreme Court: Rethinking the Court's Approach, 72 CORNELL L. REV. 905 (1987) (breaking down the Lemon test and components of judicial review for cases involving religious freedoms).

11. Lemon, 403 U.S. at $607-08$.

12. Id. at 625; Simson, supra note 10 at $905-06$.

13. Lemon, 403 U.S. at $612-13$ (internal citations omitted).

14. Alembik, supra note 10 , at 1178 .

15. Edwards v. Aguillard, 482 U.S. 578, 586-87 (1987).

16. Alembik, supra note 10, at 1179.

17. Id. 


\section{Trump v. Hawaii}

a. The Proclamations

Just days after entering office, President Trump issued the executive order that would become the first of three iterations of the "Muslim Ban." 18 The Ban played a major role in Trump's presidential campaign and enacting it fulfilled an important campaign promise. ${ }^{19}$ The executive order, and the subsequent versions of it, became known as the "Muslim Ban" because Trump first referred to his idea of the Ban by calling for "a total and complete shutdown" of Muslims entering the United States and because the President himself originally used this term. ${ }^{20}$ Shortly after the issuance of the first order, Rudy Guiliani, advisor to the President, told Fox News: "So when [Trump] first announced it, he said 'Muslim ban.' He called me up. He said, 'Put a commission together. Show me the right way to do it legally." 21 The President reiterated his call for the "shutdown of Muslims entering the United States" on numerous occasions, ${ }^{22}$ and in April 2018 called the statement "nothing to apologize for." ${ }^{23}$

The first executive order banned, for ninety days, citizens of seven predominantly Muslim countries from entering the United States. ${ }^{24}$ The original executive order was effectively struck down in Washington $v$. Trump, which ended with a "temporary restraining order blocking the

18. Trump v. Hawaii, 138 S. Ct. 2392, 2417 (2018); see Exec. Order No. 13769, 82 Fed. Reg. 8977 (Jan. 27, 2017); Exec. Order No. 13780, 82 Fed. Reg. 13209 (Mar. 6, 2017); Exec. Order No. 13780, 82 Fed. Reg. 27965 (June 14, 2017).

19. Trump's Campaign Promises - Has He Delivered on Them?, BBC NEws (Dec. 24, 2018), https://www.bbc.com/news/world-us-canada-37982000 [https://perma.cc/3DRC-NJHP]

20. Johnson, supra note 1; Trump: You Learn Very Little from Tax Returns, They Are 'Meaningless,' FoX NEWS (Jan. 23, 2017), https://www.foxnews.com/transcript/trump-you-learn-ver y-little-from-tax-returns-they-are-meaningless [https://perma.cc/LZL8-62SZ] (transcript of Trump's interview by Greta Van Susteren on May 11,2016) ("We are going to put together a group of probably five or six people. Very, very highly thought of people. And I think Rudy will head it up. And we'll look at the Muslim ban or temporary ban as we call it."); see Presidential Candidate, supra note 1.

21. Jenna Johnson, 'I Think Islam Hates Us': A Timeline of Trump's Comments about Islam and Muslims, WASH. POST (May 20, 2017), https://www.washingtonpost.com/news/post-politics/wp/2017 /05/20/i-think-islam-hates-us-a-timeline-of-trumps-comments-about-islam-and-muslims/?utm term= .cfb22992ebd2 [https://perma.cc/3PUV-7ZRZ].

22. Id.

23. The President's News Conference with President Muhammadu Buhari of Nigeria, 2018 DAILY COMP. PRES. DOC. 278 (Apr. 30, 2018), https://www.govinfo.gov/content/pkg/DCPD201800278/pdf/DCPD-201800278.pdf [https://perma.cc/4LKT-PZFC]; Adam Liptak, 'There's No Reason to Apologize' for Muslim Ban Remarks, Trump Says, N.Y. TIMES (Apr. 30, 2018), https://www .nytimes.com/2018/04/30/us/politics/trump-supreme-court-muslim-ban.html [https://perma.cc/C2LZ $-7 \mathrm{SGQ}]$.

24. Exec. Order No. 13769, 82 Fed. Reg. 8977 (Jan. 27, 2017); Jennifer Lee Barrows, Trump's Travel Ban: Lawful but Ill-Advised, 41 HARV. J.L. \& PUB. POL’Y 691, 692 (2018). 
entry restrictions." 25 The President then replaced that executive order with a new one, Executive Order No. $13780{ }^{26}$ The new executive order banned all of the same countries as the first, except for Iraq, and banned entry of all refugees for 120 days, with case by case waivers. ${ }^{27}$ Further, after the second executive order was signed, "the White House Press Secretary told reporters that ... President Trump "continue[d] to deliver on ... his most significant campaign promises.",28 Moreover, President Trump stated, "I keep my campaign promises, and our citizens will be very happy when they see the result." ${ }^{29}$ That "campaign promise," as worded by the Trump campaign, was the "total and complete shutdown of Muslims entering the United States." 30

Both orders also called for a review "to examine the adequacy of information provided by foreign governments about their nationals seeking to enter the United States." ${ }^{31}$ After completion of that review, the President issued the Proclamation that is the subject of Trump v. Hawaii, Proclamation No. 9645. ${ }^{32}$ This version of the Ban "placed entry restrictions on the nationals of eight foreign states." 33 As with the previous two bans, most of the countries banned by the Proclamation have predominantly-Muslim populations. ${ }^{34}$ However, Venezuela and North Korea were also added. ${ }^{35}$ President Trump referred to the Proclamation being reviewed by the Court as a "watered down, politically correct version" of the "original Travel Ban." 36 Shortly after issuance of the Proclamation, the President retweeted a series of anti-Muslim videos, which the White House Deputy Press Secretary related to the Proclamation, stating that the "President has been talking about these security issues for years now, from the campaign trail to the White House"

25. Trump v. Hawaii, 138 S. Ct. 2392, 2403 (2018); Washington v. Trump, No. c17-0141JLR, 2017 WL 462040, at *7-8 (W.D. Wash. Feb. 3, 2017); Barrows, supra note 24 at 693.

26. Trump, 138 S. Ct. at 2403-04; see Exec. Order No. 13780, 82 Fed. Reg. 13209 (Mar. 6, 2017).

27. Trump, 138 S. Ct. at $2404 ; 82$ Fed. Reg. at 13213-15.

28. Trump, 138 S. Ct. at 2437 (Breyer, J., dissenting).

29. $I d$.

30. Johnson, supra note 1; Peter Margulies, The Travel Ban Decision, Administrative Law, and Judicial Method: Taking Statutory Context Seriously, 33 GEO. IMMIGR. L.J. 159, 173 (2019); see also Presidential Candidate, supra note 1.

31. Trump, 138 S. Ct. at 2403-04.

32. 82 Fed. Reg. 45161 (Sept. 27, 2017).

33. Trump, $138 \mathrm{~S}$. Ct. at 2404.

34. Id. at 2421.

35. Proclamation No. 9645, 82 Fed. Reg. at 45164; Jeffrey F. Addicott, The Trump Travel Ban: Rhetoric vs Reality, 44 DAYTON L. REV. 491, 502 (2019).

36. Donald Trump (@realDonaldTrump),TwITTER (June 5, 2017, 3:29 AM), https://twitter.com /realDonaldTrump/status/871675245043888128?ref_src=twsrc\%5Etfw\%7Ctwcamp\%5Etweetembed\%7C twterm\%5E871675245043888128\&ref_url=https\%3 3 A\%2F\%2F [https://perma.cc/75LM-K77P]. 
and "has addressed these issues with the travel order that he issued earlier this year and the companion proclamation." ${ }^{37}$

The Proclamation also included case-by-case waivers and exemptions. ${ }^{38}$ However, the evidence at this point appears to show that the waivers and exemptions may not be applied in practice. ${ }^{39}$ For example, in the Proclamation's first month 6,555 applicants were eligible for a waiver but only two waivers were approved. ${ }^{40}$ Similarly, although the Proclamation purports to exempt refugees or asylum seekers, few were actually admitted entry to the United States. ${ }^{41}$ The same is true for individuals applying for a number of types of nonimmigrant visas, which were also purportedly exempt from the Ban. ${ }^{42}$ Additionally, other anecdotal evidence cited by the dissent in Trump suggests that the waiver provision is perhaps an empty promise. ${ }^{43}$

\section{b. The Case}

Trump v. Hawaii considers the constitutionality of the third version of the "Muslim Ban," Proclamation No. 9645. ${ }^{44}$ The plaintiffs in this case challenged the Proclamation on multiple grounds, ${ }^{45}$ but this Note is focused on the claim that the Proclamation is unconstitutionally based on the object of banning Muslims from the United States, violating the Establishment Clause. ${ }^{46}$

In deciding not to invalidate the Proclamation, the Court focused on the unique nature of this First Amendment claim, stating that " $[\mathrm{u}]$ nlike the typical suit involving religious displays or school prayer, plaintiffs seek to invalidate a national security directive regulating the entry of aliens abroad." 47 The Court then noted that the Proclamation is facially neutral and reasoned that based on the Court's immigration jurisprudence, the Court's "inquiry into matters of entry and national security is highly

37. See Trump, 138 S. Ct. at 2438 (Sotomayor, J., dissenting) (internal quotation marks and citation omitted).

38. Proclamation No. 9645,82 Fed. Reg. at 45165.

39. Trump, 138 S. Ct. at 2431 (Breyer, J., dissenting).

40. Id.

41. Id.

42. Id. at 2432 .

43. Id.

44. Id. at 2417; see generally, The Penn State LAW CtR. FOR IMMigrants' Rights CliniC, UPdATED FACT SHEET: MuSLim BAN CASES AT THE SUPREME COURT (2017), https://pennstatelaw.ps u.edu/sites/default/files/pictures/faculty/Muslim\%20Ban\%20Fact\%20Sheet\%206.30.17.pdf [https://p erma.cc/U696-NUXW].

45. Trump, $138 \mathrm{~S}$. Ct. at 2406 .

46. Id. at 2415-16.

47. Id. at 2418 . 
constrained." 48 The Court further reasoned that due to the touch of immigration law in this case, it could uphold the law purely because it is facially neutral, but decides not to, and to instead apply rational basis review, because the government conceded that it might be appropriate here. ${ }^{49}$ The Court, therefore, asked whether the only purpose of the Proclamation was a "bare... desire to harm a politically unpopular group." The Court found that the Proclamation had "legitimate grounding in national security concerns" and upheld the Proclamation as constitutional. $^{51}$

\section{B. Free Exercise Clause Analysis}

Two seminal cases have made the framework for answering First Amendment questions involving the free exercise of religion especially clear: ${ }^{52}$ Employment Division, Department of Human Resources of Oregon v. Smith, ${ }^{53}$ and Church of Lukumi Babalu Aye, Inc. v. City of Hialeah. ${ }^{54}$ Sections II.B.1 and II.B.2 of this Note explore these cases and their framework for Free Exercise claims, looking closely at strict scrutiny and rational basis review. Then, Section II.B.3 introduces the Court's recent case, Masterpiece Cakeshop, Ltd. v. Colorado Civil Rights Commission, and its more traditional application of the Free Exercise Clause.

The general framework for analyzing First Amendment claims, Free Exercise claims in particular, is a two-level system. First, the court decides what level of scrutiny it should use to analyze the law plaintiffs claim violated the First Amendment. ${ }^{55}$ This tier of the analysis asks whether the law is facially neutral, and if so, then the court applies a lower level of review known as rational basis, or in some cases, rational basis with bite. ${ }^{56}$ If the law singles out a group of people on impermissible grounds, then the court must apply strict scrutiny, which, as the name suggests, is a more rigid test which a law is much less likely to pass. ${ }^{57}$ The second step in the

48. Id. at 2419-20 (citing Mathews v. Diaz, 426 U.S. 67, 81-82 (1976)).

49. Id. at 2420 .

50. Id. (quoting U.S. Dep't of Agric. v. Moreno, 413 U.S. 528, 534 (1973)).

51. Id. at 2421.

52. Julia E. Pusateri, Note, Church of the Lukumi Babalu Aye, Inc. v. City of Hialeah and the Burdening of Free Exercise: The Solidification of the Employment Division v. Smith Doctrine and the Congressional Response, 38 ST. LOUIS L.J. 1041, 1041-42.

53. 494 U.S. 872 (1990).

54. 508 U.S. 520 (1993).

55. See, e.g., Babalu Aye, 508 U.S. at 531.

56. Miranda Oshige McGowan, Lifting the Veil on Rigorous Rational Basis Scrutiny, 96 MARQ. L. REV. 377, 381-82 (2012).

57. Babalu Aye, 508 U.S. at 531-32; see also Kenneth Marin, Note, Employment Division v. 
analysis is for the court to apply the appropriate test to the challenged law. ${ }^{58}$ If the law fits all the requirements of the applied test, it is upheld, and if it does not, it fails and is thus unconstitutional. ${ }^{59}$

\section{Employment Division v. Smith and Rational Basis}

In Employment Division v. Smith, the Respondents were fired because of their sacramental use of the hallucinogenic drug peyote as part of a ceremony at their Native American Church. ${ }^{60}$ The Respondents sued after the State of Oregon refused to grant them unemployment benefits, finding that they were fired for "work-related misconduct." because the criminalization of peyote burdened his ability to practice his religion, the law was unconstitutional. ${ }^{62}$ The Court disagreed. ${ }^{63}$ Instead, the Court found that "generally applicable, religion-neutral laws that have the effect of burdening a particular religious practice need not be justified [under the free exercise of religion clause of the Federal Constitution's First Amendment,] by a compelling governmental interest." 64 That is, where a law or government action is facially neutral, the court need not apply strict scrutiny. ${ }^{65}$ The Court elaborated, stating that:

[T] he "exercise of religion" often involves not only belief and profession but the performance of (or abstention from) physical acts: assembling with others for a worship service, participating in sacramental use of bread and wine, proselytizing, abstaining from certain foods or certain modes of transportation. It would be true, we think (though no case of ours has involved the point), that a State would be "prohibiting the free exercise [of religion]" if it sought to ban such acts or abstentions only when they are engaged in for religious reasons, or only because of the religious belief that they display. It would doubtless be unconstitutional,

Smith: The Supreme Court Alters the State of Free Exercise Doctrine, 40 Am. U. L. REV. 1431, 1432 (1991) ("In doing so, the Supreme Court effectively limited first amendment strict scrutiny to situations in which the government singles out a particular religion and intentionally limits the rights of its members.").

58. Babalu Aye, 508 U.S. at 531-32.

59. Id. Both Smith and Babalu Aye were superseded by the Religious Freedom Restoration Act, and now by its replacement the Religious Land Use and Institutionalize Persons Act for local zoning restrictions and for inmates. Moorish Sci. Temple of Am., Inc. v. Thompson, No. 2014-CA-001080MR, 2016 WL 1403495, at *3 (Ky. App. Apr. 8, 2016) (unreported) ("With the passage of the Religious Freedom Restoration Act ('RFRA') ... and its replacement, the Religious Land Use and Institutionalized Persons Act ('RLUIPA') . . . such a test has been superseded."). See generally Holt v. Hobbs, 135 S. Ct. 853 (2015).

60. Emp't Div. v. Smith, 494 U.S. 872, 874 (1990).

61. Id. (internal quotation marks omitted).

62. Id. at 875 .

63. Id. at 890 .

64. Id. at $886 \mathrm{n} .3$.

65. Id. 
for example, to ban the casting of "statues that are to be used for worship purposes," or to prohibit bowing down before a golden calf. ${ }^{66}$

What the Court did not do in Smith, however, was directly apply the rational basis test as we know it today. ${ }^{67}$ At least, not in the same terms. ${ }^{68}$ Instead, the Court simply stated that '[b]ecause respondents' ingestion of peyote was prohibited under Oregon law, and because that prohibition is constitutional," the refusal of employment benefits was not prohibited by the Constitution. ${ }^{69}$

Rational basis review has its own line of jurisprudence, dating back to $1914 .^{70}$ The test for rational basis review provides that "if a law neither burdens a fundamental right nor targets a suspect class, we will uphold the legislative classification so long as it bears a rational relation to some legitimate end." 71 There are then two essential questions involved in the application of rational basis review. ${ }^{72}$ First, does the law burden a fundamental right or target a suspect class? If the answer to this question is yes, the court applies strict scrutiny. ${ }^{73}$ If the answer is no, the Court moves on to the second question: does the law at issue bear "a rational relation to some legitimate end[?]"74 The Court has also applied what is typically known as the rigorous rational basis test or rational basis with bite, although it has not formally accepted it as a separate test from the usual rational basis. ${ }^{75}$ When the Court uses the more rigorous test, it looks more deeply into the State's motivation for the law at issue, even where

66. Id. at $877-78$.

67. See id. at $883-84$.

68. Id.

69. Id. at 890 .

70. Nicholas Walter, The Utility of Rational Basis Review, 63 VILL. L. REV. 79, $83-84$ (2018) ("The first appearance of the 'rational basis' language in the Supreme Court came in the 1914 case of Singer Sewing Machine Co. v. Brickell. There, the Court upheld against an equal protection challenge an Alabama statute that provided that itinerant sellers of sewing machines should pay an annual tax for each county in which they operated, but non-itinerant sellers of sewing machines should not pay a tax. The Court noted that there was an evident difference between selling sewing machines as an itinerant merchant and doing so from a fixed establishment, and it was unable to say that this distinction was 'arbitrar[y]." (citations omitted)).

71. Romer v. Evans, 517 U.S. 630, 631 (1996); see also James M. McGoldrick, Jr., The Rational Basis Test and Why It Is So Irrational: An Eighty-Year Retrospective, 55 SAN DIEGO L. REV. 751, 771 (2018) ("[W]ith the rational basis test, the Court appears to invent ways the law might advance the legitimate end - whether realistic or not. ... [T] $]$ he Court is clear that the rational basis test does not require any consideration as to whether other alternatives might better address the problem.").

72. Romer, 517 U.S. at 631

73. Id.

74. Id.; see also John F. Manning, The Absurdity Doctrine, 116 HARV. L. REV. 2387, 2451 (2003) ("[A] court must give effect to a rational classification even if it is to some extent both underinclusive and overinclusive in relation to its apparent purpose." (internal quotation marks omitted)).

75. McGowan, supra note 57, at 381-82 ("The Supreme Court, however, has never squarely admitted — and indeed, has sometimes denied — that a rigorous form of rational basis scrutiny exists."). 
that law is facially neutral. ${ }^{76}$

For example, in Plyler v. Doe, the Court struck down a Texas law that refused funding to schools for the education of undocumented immigrants as a violation of the Equal Protection Clause. ${ }^{77}$ Even though the law did not target a suspect class or burden a fundamental right, the Court refused to accept Texas's flawed reasoning for the law as a rational basis reasonably related to a legitimate aim. ${ }^{78}$ The State alleged that the reasoning for the law was "to protect itself from an influx of" undocumented immigrants. ${ }^{79}$ The Court, however, stated that "[t]here is no evidence in the record suggesting that illegal entrants impose any significant burden on the State's economy. To the contrary, the available evidence suggests that illegal aliens underutilize public services, while contributing their labor to the local economy and tax money to the state fisc." ${ }^{\prime 80}$ In Plyler, the Court, applying rational basis review, did not merely accept the purpose asserted by the government without question because there was little evidence to support a finding that the law actually pursued some legitimate state goal. ${ }^{81}$ Instead, the glaring mismatch between ends and means in this case led the Court to strike down the law. ${ }^{82}$

\section{Babalu Aye and Strict Scrutiny}

Yet another test the Court may use to analyze a First Amendment claim is strict scrutiny. ${ }^{83}$ Church of the Lukumi Babalu Aye, Inc. v. City of Haileah provides a remarkable example of this analysis where the Court considers government statements. Babalu Aye addressed the constitutionality of four Florida city ordinances making animal sacrifice punishable by fines up to five hundred dollars, sixty days of imprisonment,

76. Id. at 383-84 ("As with strict and intermediate scrutiny, when the Court applies rigorous rational basis scrutiny it presumes that the legislation is unconstitutional. The state must prove that the law has a legitimate state purpose and that the classification furthers the state interest. As with strict and intermediate scrutiny, not all state interests suffice to discharge the state's burden. Moral objections to the group's conduct or to the group itself, under-inclusive or over-inclusive justifications will not discharge the state's burden." (citations omitted)).

77. 457 U.S. 202, 230 (1982).

78. Id. at $228-29$.

79. Id. at 228 .

80. Id.

81. Id.

82. Id. at 230 .

83. Church of the Lukumi Babalu Aye, Inc. v. City of Hialeah, 508 U.S. 520, 546 (1993); Kenji Yoshino, The New Equal Protection, 124 HARV. L. REV. 747, 756 (2011) ("The Supreme Court has formally accorded heightened scrutiny to classifications based on five characteristics - race, national origin, alienage, sex, and nonmarital parentage." (internal citations omitted)). 
or both. ${ }^{84}$ The petitioner, Church of Lukumi Babalu Aye, and its members practiced the Santeria religion, and used animal sacrifice as a form of devotion. ${ }^{85}$ Because the ordinances would punish the practice of the Church's religion, the Church challenged them as a violation of the First Amendment's Free Exercise Clause. ${ }^{86}$

In Babalu Aye, the Court began its analysis by addressing whether the ordinances at issue are neutral and of general applicability. ${ }^{87}$ Importantly, the Court noted that "[n]eutrality and general applicability are interrelated, and, as becomes apparent in this case, failure to satisfy one requirement is a likely indication that the other has not been satisfied." ${ }^{88}$ In deciding whether a law is neutral, Babalu Aye reasoned that where the purpose of a law is to inhibit actions or "practices because of their religious motivation, the law is" not considered neutral. ${ }^{89}$

The Court continued to discuss the multiple avenues used to determine the object or purpose of a law. ${ }^{90}$ First and foremost, the analysis should consider the text of the law and whether it is discriminatory on its face, explaining that a law "lacks facial neutrality if it refers to a religious practice without a secular meaning discernable from the language or context." 91 However, the Court made it incredibly clear that facial neutrality is not enough to prove that a law actually has a neutral purpose, stating that:

Facial neutrality is not determinative. The Free Exercise Clause, like the Establishment Clause, extends beyond facial discrimination. The Clause "forbids subtle departures from neutrality" ... and "covert suppression of particular religious beliefs ...." Official action that targets religious conduct for distinctive treatment cannot be shielded by mere compliance with the requirement of facial neutrality. The Free Exercise Clause protects against governmental hostility which is masked, as well as overt.

84. Babalu Aye, 508 U.S. at 528 ("All ordinances and resolutions passed the city council by unanimous vote. Violations of each of the four ordinances were punishable by fines not exceeding $\$ 500$ or imprisonment not exceeding [sixty] days, or both.").

85. Id. at 524 .

86. Id. at 528 .

87. Id. at 531 ("In addressing the constitutional protection for free exercise of religion, our cases establish the general proposition that a law that is neutral and of general applicability need not be justified by a compelling governmental interest even if the law has the incidental effect of burdening a particular religious practice."); see Brian A. Freeman, Trends in First Amendment Jurisprudence: Expiating the Sins of Yoder and Smith: Toward a Unified Theory of First Amendment Exemptions From Neutral Laws of General Applicability, 66 Mo. L. REV. 9, 18 (2001) ("Of particular importance in Babalu Aye is that, for the first time in a First Amendment religion case, the Court attempted to define precisely the meaning of neutral and generally applicable." (internal quotation marks omitted)).

88. Babalu Aye, 508 U.S. at 531.

89. Id. at 533 .

90. Id.

91. Id. 
"The Court must survey meticulously the circumstances of governmental categories to eliminate, as it were, religious gerrymanders. $" 92$

Thus, the Court went on to state that even if the law is facially neutral, the analysis should consider "the effect of a law in its real operation," which is also considered "strong evidence of its object." "93 For example, in Babalu Aye, the prohibition on killing animals was interpreted by the government to include religious animal sacrifice, but exclude most other killings. ${ }^{94}$ Thus, although the prohibition itself was worded neutrally, in practice, it targeted those of the Santeria religion. ${ }^{95}$

The Court also considered the relation of the law to the proposed governmental interest. ${ }^{96}$ To be considered neutral in purpose, the law at issue must relate to the legitimate governmental interest and cannot be over or under inclusive. ${ }^{97}$ Here, for example, the proposed governmental interest was to prevent cruelty to animals and protect public health. ${ }^{98}$ However, the Court reasoned that "[i]f improper disposal, not the sacrifice itself, is the harm to be prevented, the city could have imposed a general regulation on the disposal of organic garbage," and that "[w]ith regard to the city's interest in ensuring the adequate care of animals, regulation of conditions and treatment, regardless of why an animal is kept, is the logical response to the city's concern, not a prohibition on possession for the purpose of sacrifice." 99

The Babalu Aye Court further looked to Equal Protection cases for guidance, importantly noting:

Relevant evidence includes, among other things, the historical background of the decision under challenge, the specific series of events leading to the enactment or official policy in question, and the legislative or administrative history, including contemporaneous statements made by members of the decisionmaking body. These objective factors bear on the question of discriminatory object. ${ }^{100}$

Here, the Court looked to the events leading up to the ordinances as

92. Id. at 534 (citing Gillette v. United States, 401 U.S. 437, 452 (1971); Bowen v. Roy, 476 U.S. 693, 703 (1986); Walz v. Tax Comm'n of N.Y. City, 397 U.S. 664, 696 (1970) (Harlan, J., concurring) (internal quotations omitted)).

93. Babalu Aye, 508 U.S. at 535.

94. Id. at 535 .

95. Id. at 542 .

96. Id. at $538-39$.

97. Id. at 533-34.

98. Id. at 538 .

99. Id. at 538-39.

100. Id. at 540 . 
evidence of their discriminatory intent. ${ }^{101}$ Specifically, the Court found that because no discussion of animal sacrifice happened in the city council until the Church announced its opening and because councilmembers and residents made discriminatory comments about the religion and how to stop the Church from opening during a recorded session, there was significant evidence to show that the purpose of the ordinances was not neutral. ${ }^{102}$ Because the ordinances were not neutral, the Court applied strict scrutiny, a test in which the government action at issue is only constitutional if the government can show that it is "narrowly tailored" and advances "interests of the highest order." 103

\section{Masterpiece Cakeshop v. Colorado Civil Rights Commission.}

In Masterpiece Cakeshop v. Colorado Civil Rights Commission the Court took an entirely different tone than in Trump. ${ }^{104}$ The controversy at the core of Masterpiece began when Jack Phillips, the owner of a bakery in Colorado, refused to bake a wedding cake for a gay couple. ${ }^{105}$ After the refusal, the couple filed a complaint at the Colorado Civil Rights Commission based on a Colorado law prohibiting discrimination based on sexual orientation in businesses that sell goods or offer services to the public. ${ }^{106}$ The administrative law judge at the Commission hearing ruled in the couple's favor, finding that the baker's First Amendment rights would not have been violated by having to bake a cake for the couple, and ultimately, the Colorado Court of Appeals affirmed the decision. ${ }^{107}$

While the Court in Masterpiece recognized that laws protecting gay persons and gay couples are often not considered unconstitutional, it found that in this case, the Commission "showed elements of a clear and impermissible hostility toward the sincere religious beliefs motivating [the baker's] objection." "108 The Court found the Commission's decision impermissible based on two grounds. ${ }^{109}$ First, some Commissioners made statements about the baker's religion during the public hearing on the

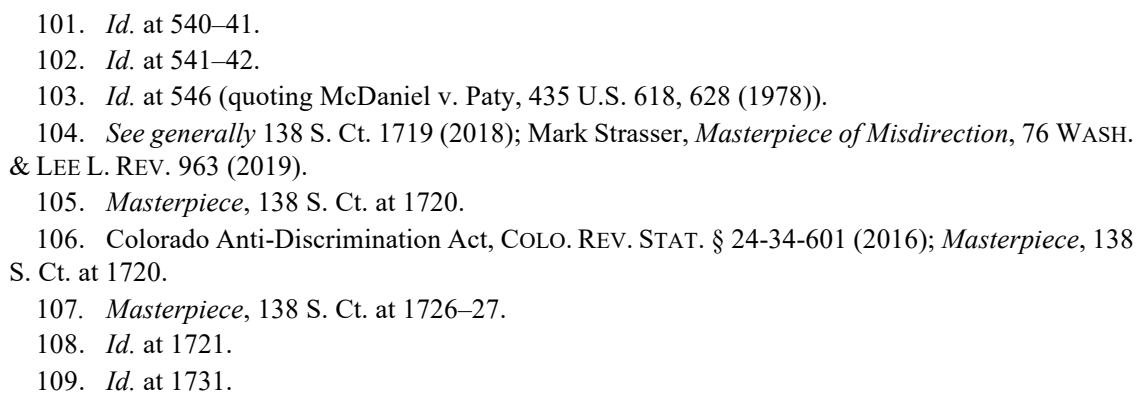


matter. ${ }^{110}$ Second, the Commission had treated cases of refusal to put antigay statements on cakes differently than the case at hand. ${ }^{111}$ Importantly, the Court in Masterpiece considered the above points (the statements and unequal treatment) as evidence of a lack of neutrality, despite the neutral text of the law. ${ }^{112}$

\section{ANALYSIS}

The decision in Trump, especially as compared to Masterpiece, raises important questions about the Court's use of government statements in Establishment and Free Exercise Clause claims and of its eagerness to ignore such statements when "national security" is the justification of the government. This Note argues first that Trump's analysis under the Establishment Clause is unusual, and the case would have been more aptly analyzed under the Free Exercise Clause. Second, it argues that even under the Establishment Clause framework, the Proclamation should not have been upheld. Third, this Note analyzes Trump under the Free Exercise Clause, arguing that the statements in Trump are no different than those in Free Exercise cases where the Court found the government action unconstitutional. Lastly, this Note argues that when cases like Trump arise in the future, courts should analyze them under the Free Exercise Clause and not the Establishment Clause. Further, in this analysis, the Court should avoid an overly broad loophole which would make executive action essentially unreviewable when immigration is at issue. Cases where the Executive has such great power should, in the future, be reviewed with some scrutiny, especially when that executive repeatedly makes remarks about his disdain for a particular suspect class. The Court's decision, therefore, should not be read broadly to destroy all meaningful review of executive actions which are purportedly based on national security. Such a reading could have disastrous results.

A. Because Trump Involved Government Animus Towards Religion, It Should Have Been Analyzed as a Free Exercise Claim, Rather Than an Establishment Clause Claim.

Some of the peculiarity of Trump likely stems from the fact that despite looking more like the traditional Free Exercise claim, it was brought and analyzed as an Establishment Clause claim. ${ }^{113}$ Generally, the

\footnotetext{
110. Id. at 1721 .

111. Id. at 1730 .

112. Id. at 1722

113. See supra Section II.A.2.
} 
Establishment Clause is invoked against government action that benefits a religion or religious organization. ${ }^{114}$ The Lemon test itself seems to indicate that this is the case. ${ }^{115}$ For example, the entanglement prong of the test seems designed to deal with situations in which the government somehow advances a religious institution. ${ }^{116}$ Conversely, it hardly makes sense to ask if a government action seeking to condemn or marginalize a religion somehow creates excessive entanglement with religion, as this would almost certainly never be the case. The government action at issue in Trump does not seek to advance any religion, nor does it benefit any religious institution, as is typically the case with Establishment Clause cases. ${ }^{117}$ Instead, it looks factually much more like the Free Exercise cases discussed above, including Masterpiece, which typically involve government action against a religion and which take the government statements surrounding the action very seriously. ${ }^{118}$ Further, the Court adds to the confusion by not applying the Lemon test, as is the usual case for Establishment claims, but rather, applying rational basis review, which is generally used in Free Exercise claims.

The eventual Establishment Clause claim likely stems from some avoidance of standing issues in the claim. Because the alleged Free Exercise violation occurred against people who were likely not U.S. citizens and were not in the United States, it may have been difficult to show that those prohibited from entering the United States had standing to sue. ${ }^{119}$ It seems that the decision to bring the claim under the Establishment Clause, with plaintiffs alleging injury in the form of the exclusion of their relatives by the Proclamation, may have been a litigation choice made to avoid these issues. ${ }^{120}$ Assuming standing requirements could be met, a Free Exercise claim would make much more sense, as shown below. However, even under traditional Establishment Clause analysis, the Proclamation should have been considered unconstitutional because it has the effect of excluding a religion.

\footnotetext{
114. See, e.g., Lemon v. Kurtzman, 403 U.S. 602 (1971).

115. Id. at 612 .

116. Id. at 612-14.

117. See generally Trump v. Hawaii, 138 S. Ct. 2392 (2018)

118. See supra Section II.B.

119. See Trump, 138 S. Ct. at 2416; see also Earl M. Maltz, The Constitution and the Trump Travel Ban, 22 LEWIS \& Clark L. Rev. 391, 406-07 (2018). Cf. Ryan M. Mardini, Note, The "Muslim Ban" and the Constitutional Crisis, 96 U. DET. MERCY L. REV. 225, 248 (2019) ("But why is the Establishment Clause a much better avenue of challenging the order? The Establishment Clause prohibits government preferentialism of one religion over another, providing a natural foundation for a constitutional claim.").
}

120. Trump, 138 S. Ct. at 2416. 


\section{B. The Proclamation Fails the Lemon Test, Which Would Usually Be} Applied in an Establishment Clause Case.

The fact that the plaintiffs in Trump based their claim in the Establishment Clause is peculiar, although perhaps necessary, on its own. However, it is the Court's failure to actually apply the traditional Establishment Clause framework that completely muddles the decision. Ideally, the Court would have analyzed Trump under the Free Exercise analysis explored below. But even if the Court had used the Lemon test, as it does in other Establishment Clause cases, the Proclamation likely would have been ruled unconstitutional based, at the very least, on its practical effect.

The Proclamation may arguably not even meet the first prong of the Lemon test, secular purpose. Although the Proclamation does have the purported secular purpose of increasing national security, a court could find that this is a "sham." 121 Of course, this would require the Court to give quite a bit of weight to Trump's statements about the Ban, which it seems reluctant to do, especially when national security is at issue. ${ }^{122}$ But, even if the Proclamation passed the first prong, it would almost certainly fail the second, which requires that the practical effect of government action is not to condemn a religion. ${ }^{123}$ The Proclamation is, in effect, the "Muslim Ban" that Trump proposed during his campaign. While the Trump Administration has certainly dressed up the Proclamation in an attempt to avoid judicial scrutiny, the outcome of its terms is to merely ban citizens of predominantly-Muslim countries from entering the United States without any evidence that they have any connection to terrorism or present a threat to the United States. ${ }^{124}$ The third prong of the Lemon test is nearly impossible to apply to Trump because the Proclamation does not benefit a religion or religious institution, but it is also not necessary to apply due to the failure at prong two.

\section{Applying the Free Exercise Clause to the Proclamation.}

Two aspects of the Proclamation make it unlikely that the Court could find the government acted constitutionally under the traditional Free Exercise analysis which it should have applied. First, as was the case in

121. Cf. Edwards v. Aguillard, 482 U.S. 578, 586-87 (1987) ("While the Court is normally deferential to a State's articulation of a secular purpose, it is required that the statement of such purpose be sincere and not a sham.").

122. See Trump, 138 S. Ct. at 2416.

123. Alembik, supra note 10, at 1179.

124. See infra notes $138-60$ and accompanying text. 
Masterpiece, the Court would likely find that statements of Trump and members of his campaign make it clear that the Proclamation had a discriminatory object. Second, and again as in most Free Exercise cases, the Court would have considered the mismatch between the purported intent of the Proclamation and its actual effect as applied.

\section{Statements as Evidence of Neutrality}

One unresolved question from Trump is the weight the Court gives to statements by government officials. In Trump, the Court emphasized that the Proclamation is "facially neutral toward religion." "25 And, in deciding which level of scrutiny to apply, the Court did not consider the antiMuslim statements of the Trump Administration. ${ }^{126}$ But, in Masterpiece, although the text of the regulations in Colorado was facially neutral towards religion, as was the Proclamation, the same Court viewed the government statements in that case as evidence that the government did not act neutrally. ${ }^{127}$ Yet, the statements in Trump, if analyzed in the usual manner, almost certainly show a lack of neutrality on the part of the government. In Masterpiece, the problematic statement that proved a lack of neutrality was a commission member stating that he found using one's religion to discriminate against gay people "despicable." 28 This is comparable to statements like "Islam hates us" or "shutdown of Muslims entering the United States." 129 Further, the President's statements are perhaps even more evidence of a lack of neutrality than those in Masterpiece because he is the sole executive issuing the executive orders at issue, while in Masterpiece, there was more than one Commissioner making the decision. The President's statements also span months before, during, and after all three versions of the Ban, and explicitly state that each version had the same purpose as the first, which he called a "Muslim Ban" himself. ${ }^{130}$

A comparison of Trump to Babalu Aye and Smith further show how, if the court had applied its usual analysis, the Proclamation likely would not have been upheld. First, the Court in Smith, applied rational basis

\footnotetext{
125. Trump, $138 \mathrm{~S}$. Ct. at 2418.

126. Id. at $2418-20$.

127. Masterpiece Cakeshop, Ltd. v. Colo. Civil Rights Comm'n, 138 S. Ct. 1719, 1729 (2018).

128. Id.

129. Johnson, supra note 21; Liptak, supra note 23; Presidential Candidate, supra note 1; Theodore Schleifer, Donald Trump: 'I Think Islam Hates Us, ' CNN (Mar. 10, 2016, 5:56 PM), https:// www.cnn.com/2016/03/09/politics/donald-trump-islam-hates-us/ [https:/perma.cc/ZKZ6-AHMV]. But cf. Addicott, supra note 35 at 525-26 (discussing disagreement among members of the Supreme Court over whether Trump's statements are evidence of animus or an unorthodox speaking style).

130. Johnson, supra note 21.
} 
review to review a ban on smoking peyote because the Court found that law was indeed neutral and "generally applicable." 131 There were no statements from the government suggesting that the ban on the drug was motivated by animus towards a particular religion, nor was there evidence that the law was unfairly applied to religious people. ${ }^{132}$ The lack of factors showing an impermissible purpose makes Smith wholly different from Trump, and suggests that, had the Court applied the Free Exercise analysis in Trump, it would have applied some heightened scrutiny. This was the case in Babalu Aye, which is much more similar to Trump than Smith. ${ }^{133}$ There, even though the law was facially neutral and applied to everyone, the government had made statements that suggested it was really a way to stop the building of a church. ${ }^{134}$ The Court there emphatically stated that "facial neutrality is not determinative," 135 and that the First Amendment forbids "covert suppression of particular religious beliefs." 136 The Proclamation would not pass the test set out in Babalu Aye because the President's consistent and discriminatory statements make it highly unlikely that the Proclamation is neutral. Under a Babalu Aye standard, the Court would have applied strict scrutiny, especially considering the application of the Proclamation in practice.

\section{Application as Evidence of Neutrality}

Another area in which the Court's treatment of Masterpiece and Trump differs is in reviewing the laws at issue as they are applied. The Court in Masterpiece points to an unfair application of the law by the Commission as evidence of a lack of neutrality on the part of the Government. ${ }^{137}$ Just as with the statements, this may well be the case with the Proclamation, too. ${ }^{138}$ The Proclamation is for the supposed purpose of national security, but it would be wildly over-inclusive to deem every single person from eight different nations - 150 million people - a threat to national security. ${ }^{139}$ In fact, "no national from any of [the] countries

\footnotetext{
131. Emp’t Div. v. Smith, 494 U.S. 872, 882 (1990).

132. See generally id.

133. Church of Lukumi Babalu Aye, Inc. v. City of Hialeah, 508 U.S. 520, 533-34 (1993).

134. Id.

135. Id.

136. Id. (quoting Bowen v. Roy, 476 U.S. 693, 703 (1986)).

137. Masterpiece Cakeshop, Ltd. v. Colo. Civil Rights Comm'n, 138 S. Ct. 1719, 1730-31 (2018).

138. Trump v. Hawaii, 138 S. Ct. 2392, 2431 (2018) (Breyer, J., dissenting).

139. See James R. Clapper et al., We've Worked on Stopping Terrorism. Trump's Travel Ban Fuels It $t$ HARV. KENNEDY SCH. BELFER CTR. FOR SCI. \& INT'L AFF. (Apr. 23, 2018), https://www.belfercent er.org/publication/weve-worked-stopping-terrorism-trumps-travel-ban-fuels-it [https://perma.cc/ECL 7-LQ7W] (explaining that the ban bars 150 million people and arguing that only a few of those are legitimate national security threats).
} 
[included in the Ban] has caused any of the terrorism-related deaths in the United States since 1975."140 The application of waivers and exemptions would alleviate this over-inclusiveness, suggesting a more individual approach that indeed targeted dangerous people. ${ }^{141}$ However, the evidence indicates that these waivers are not actually being applied in a manner that would undo the over-inclusive nature of the Proclamation. ${ }^{142}$ Only around two percent of the waiver applications received through April 30, 2018 were actually approved, ${ }^{143}$ and, as of the issuance of Trump, consular officials had not even received any guidance on how or when to grant waiver applications. ${ }^{144}$ In other words, there is no transparent system even in place to apply the purported waivers, ${ }^{145}$ which would need to be extensive to avoid over-inclusivity. ${ }^{146}$

Further, the Proclamation is under-inclusive because it does not ban individuals from the countries that have produced the most foreign-born terrorists. ${ }^{147}$ In fact, the country that is number one on the list of Country of Origin for most foreign-born terrorists responsible for the deaths of American citizens from 1975 to 2015, Saudi Arabia, is not included in the Proclamation. ${ }^{148}$ The countries included in the Ban are not even in the top twenty-five of that list. ${ }^{149}$ If the Proclamation actually sought to limit dangerous people coming to the United States, it should have banned the

140. Id.

141. See, e.g., Looking Back and Fighting Forward on the One-Year Anniversary of Muslim Ban 3.0, NAT'L IMMIGRATION LAW CTR. (Oct. 2018), https://www.nilc.org/issues/immigration-enforceme nt/muslim-ban3-1-year-anniversary-facts/ [https://perma.cc/53CX-YPJU] [hereinafter Looking Back] ("[The waiver process] is the only mechanism and hope for individuals from the banned nations to obtain a visa. However, the waiver process is a sham. There is no formal process or application, and most cases have either been denied or indefinitely put on hold.").

142. Trump, 138 S. Ct. at 2431 (Breyer, J., dissenting).

143. Vahid Niayesh, Trump's Travel Ban Really Was a Muslim Ban, Data Suggests, WASH. POST (Sept. 26, 2019, 4:00 AM) https://www.washingtonpost.com/politics/2019/09/26/trumps-muslimban-really-was-muslim-ban-thats-what-data-suggest/.

144. Id.

145. Id.

146. See, e.g., Looking Back, supra note 141.

147. Peter Margulies, Bans, Borders, and Sovereignty: Judicial Review of Immigration Law in the Trump Administration, 2018 MICH. ST. L. REV. 1, 66(2018) ("EO-3 is markedly under-inclusive in certain respects, omitting countries such as Bangladesh, Bosnia-Herzegovina, Kenya, Pakistan, and Uzbekistan that together accounted for substantially more terrorism related [sic] conduct than countries listed in the Proclamation."); W. Bradley Wendel, Government Lawyers in the Trump Administration, 69 HASTINGS L.J. 275, 345 (2017) (arguing that the Proclamation "makes no effort to increase scrutiny of entrants from countries presenting a real and present terrorist threat").

148. Uri Friedman, Where America's Terrorists Actually Come From, ATLANTIC (Jan. 30, 2017), https://www.theatlantic.com/international/archive/2017/01/trump-immigration-ban-terrorism/514361 / [https://perma.cc/7VJF-3AMY].

149. Id. 
countries statistically shown to have the most dangerous people. ${ }^{150}$ And, even soon after the issuance of the Proclamation, it was clear that not only did the Ban not achieve its purported goals, it actually did the opposite. ${ }^{151}$ Chad, for example, offended by its inclusion in the Ban, removed its troops from Niger, where they were cooperating with a counterterrorism struggle against Boko Haram. ${ }^{152}$

Some will likely point to the inclusion of Venezuela and North Korea, the only two non-majority-Muslim countries included in the Proclamation, as evidence that the Ban is not actually targeting Muslims. But two important details make it clear these inclusions are likely a paper tiger, included only to skirt passed the scrutiny of the courts. First, the two countries were only added after the first version of the Ban was struck down. ${ }^{153}$ Second, in practice, very few (if any) people from North Korea seek visas in the United States, and when it comes to Venezuela, the executive order only applies to "a handful of officials and their families." 154 The addition of these two countries thus has little to no practical effect on the outcome of the Proclamation, and the addition was made only after the failure of the first executive order in the Ninth Circuit, ${ }^{155}$ in Trump's own words "water[ing] down" the Proclamation. ${ }^{156}$

Thus, when one considers the statements of the Trump Administration and the practical effect of the Proclamation, it seems to be anything but neutral. If the Court had analyzed the case under the more typical Free Exercise framework, like in Masterpiece, it almost certainly would not have been upheld. However, the Court invokes the fact that the Proclamation is a "national security directive" as reasoning to not look beyond the face of the executive order at all and refuse to question the government's purported purpose at all. ${ }^{157}$ But the Court then decides to apply rational basis review. ${ }^{158}$ The only explanation the Court gives for why it chose that level of review is that the government suggested that

150. Proclamation No. 9645, 82 Fed. Reg. 45161 (Sept. 24, 2017); see Marguiles, supra note 147, at 66; Wendel, supra note 147, at 345 .

151. Clapper et al., supra note 139.

152. Id.

153. Compare Exec. Order No. 13780, 82 Fed. Reg. 13209 (Mar. 6, 2017), with Proclamation No. 9645,82 Fed. Reg. at 45161.

154. Rick Gladstone \& Satoshi Sugiyama, Trump's Travel Ban: How It Works and Who Is Affected, N.Y. TIMES (July 1, 2018), https://www.nytimes.com/2018/07/01/world/americas/travel-ban -trump-how-it-works.html [https://perma.cc/RC5X-WVQH].

155. See Washington v. Trump, 858 F.3d 1168, 1168 (9th Cir. 2017).

156. Donald Trump, supra note 36.

157. Trump v. Hawaii, 138 S. Ct. 2392, 2418 (2018).

158. Id. at 2420 . 
looking beyond the face of the Proclamation may be appropriate. ${ }^{159}$ This is an odd and flawed approach, suggesting that whenever the President acts on admission and immigration matters, it cannot be questioned beyond the carefully planned text of the executive order (and Trump's case, reissued three times to find just enough facial neutrality to calm the courts), unless the government allows a more in-depth analysis. Instead, the statements behind the Proclamation and its unfair application should have triggered a higher level of review. And even under rational basis review, these same factors would likely lead to the striking down of the Proclamation. ${ }^{160}$

\section{Immigration and National Security as an Overly Broad Loophole}

The Court in Trump invokes a number of cases involving immigration or national security to justify its claim that the Court need not look beyond the face of the Proclamation. ${ }^{161}$ The first of these cases is Kleindienst $v$. Mandel, in which a self-described Marxist and Belgian journalist was denied entry to the United States where he was going to speak at Stanford University. ${ }^{162}$ The students sued, alleging that their constitutional right to receive information had been infringed by the denial. ${ }^{163}$ A singular visa denial was also at issue in Kerry v. Din, ${ }^{164}$ where a woman and U.S. citizen sued based on a protected liberty interest in her marriage when her husband's visa application was denied due to his connection to the Taliban. ${ }^{165}$ The Trump Court also invokes Fiallo v. Bell, where the Court considered a congressionally imposed definition of "parent" in immigration that discriminated on the basis of sex. ${ }^{166}$

In all of these cases, the Court asked only whether the policy is "facially legitimate and bona fide."167 Importantly, the first two of these cases apply only to a singular visa denial, based on direct and particular evidence that the person in question was a threat to the United States. ${ }^{168}$ The third case applied to congressional action - passed by both the House and the Senate and signed by the President — which while discriminatory on the basis of sex, was most likely not based on an animus towards

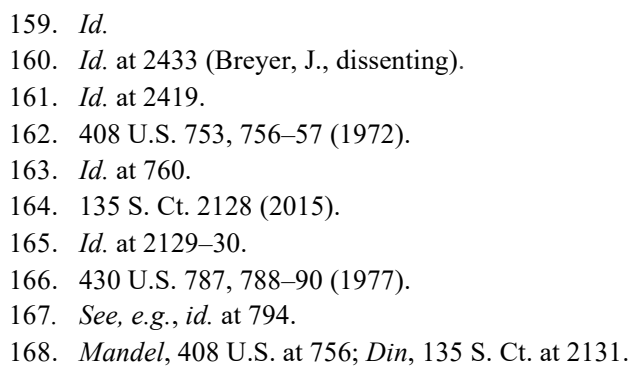


men. ${ }^{169}$ These details are important to compare to the Proclamation at issue in Trump.

The Court invokes the national security and immigration piece of the Proclamation, saying that it need not apply the traditional domestic Establishment Clause framework for this reason. ${ }^{170}$ Instead, the Court says it must only apply a very deferential test it previously applied to congressional acts and the denial of a single person's visa. ${ }^{171}$ But the Court does not, in the end, apply that deferential test. The Court instead decides to apply rational basis review. ${ }^{172}$ The Court does not explain its decision to apply rational basis review to the Trump Proclamation beyond stating that the government suggested it may be appropriate. ${ }^{173}$ This is perhaps the most confusing piece of the Trump decision: its use of immigration and national security to justify not looking beyond the face of the Proclamation, and what that means for future cases. For this reason, the Court should seek to make several clarifications of its analysis here as future cases arise.

First, the Court must clarify if a new category of cases now exists that is analyzed neither under the Immigration or Foreign Relations framework, which would apply a "facially legitimate and bona fide" standard, ${ }^{174}$ nor under the Establishment or Free Exercise Clause framework, which would apply the Lemon test or heightened scrutiny. The Court here states that it need only apply the "facially legitimate and bona fide" standard, but then does not apply it. Future cases should help explain why the court did not apply that standard. The Court must clarify what about the Trump case made it worthy of rational basis review. Is it the case that only where the government itself expressly suggests or permits the court to look beyond a facial justification of national security, the Court will, but apart from that it will not? Or is it something about the facts of this particular case that drove the Court to stray from what it says is the appropriate analysis? If it is something about the facts, the Court should eventually elaborate on which facts led to that decision, and if other cases may also fit into this Immigration-Establishment Clause middle category.

Second, the Court seems to suggest that it will not look beyond the face of any law that involves "admission and immigration" and "overlap[s] with "the area of national security." "175 This category is vague, broad, and

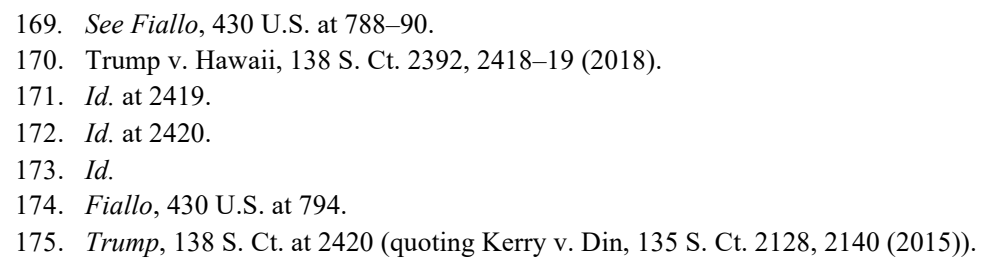


could very well include every immigration-related government action. As future cases involving immigration arise, the Court should clarify, and hopefully narrow, the cases that would invoke such deferential treatment. This is especially important considering the Court's opinion suggests that even facially discriminatory immigration measures can be upheld under Fiallo. ${ }^{176}$ Consider, for example, a travel ban that explicitly bans noncitizen Muslims from entering the United States, which the President justifies with national security. That case would look much like Trump, and, although it would not pass the rational basis test, if Fiallo appliedas the Court seems to suggest it does - the measure would still be upheld because the government used the facially legitimate purpose of national security. This result would be absurd, and the Court should clarify that the President may not justify discrimination against a particular religious group simply by crying national security.

Further, there are several reasons why the Court should not shy away from imposing a more rigorous scrutiny on executive action involving immigration in the future. First, action where the executive acts alone, without Congress, should garner stricter review than cases where more than one branch of government is involved. This is because action where more people must agree is subject to its own checks and review during the legislative process, whereas Executive action is subject only the to the check of the Court. If the Court does not meaningfully review executive action relating to immigration, then the executive acts, essentially, unchecked. Second, it is nonsensical to require only the legitimate reason of national security immigration-related actions because every single immigration-related action could be justified by national security. Such a test is not a test at all, as every single law would be upheld under it, especially now that drafters of such laws and orders know that simply including national security can help avoid review by the courts. Lastly, in matters of foreign relations and immigration, the President's words matter perhaps even more than in other areas of the law because the President is the sole voice of the nation on these issues. Whether or not the Court wants to acknowledge the reality of these statements, other nations will, and they can have extremely negative consequences. ${ }^{177}$ Thus, even where an executive invokes national security as a justification for his immigration-related action, the Court should not be afraid to look beyond that justification and consider the President's statements and other blatant evidence of discriminatory purpose.

176. Id. at 2419 .

177. See supra note 151. 


\section{E. Reading Trump Narrowly}

Considering the unusual analysis used by the Court in Trump, and the clarifications that would be needed to fully understand its effect on the law, the lower courts should read Trump as narrowly as possible. First, the nearly nonexistent standard of review in Trump should not be read as to apply to all Establishment Clause cases. We can see this based on the Court's opinion decided the same term in Masterpiece, where it applied the traditional First Amendment framework. Second, courts should not read Trump as applying to all immigration-related government action, even if facially discriminatory under Fiallo, Mandel, and Din. Because the Trump Court did not in the end apply these cases leaves the question of when they apply open. Courts should thus proceed as if Trump adds nothing on this point and consider the facts of the particular case, as they would have before Trump. Trump should not be read as broadening the President's power in immigration to include the ability to do anything as long as it is facially justified by national security. Lastly, in considering Trump's precedential effect, courts should consider that the Proclamation at issue included exceptions and waivers, required findings by U.S. security organizations, and was redrafted twice after being found unconstitutional. These factors which can point to facial neutrality and a reasonable relation to a legitimate government interest, although not actually meaningful in the application of the Proclamation, should be present in any case where a court seeks to apply the standard of review in Trump.

\section{CONCLUSION}

The President should not be permitted to discriminate on the basis of religion by merely claiming a national security justification. Nor should the executive see the constitutional requirements of the Establishment Clause and the Free Exercise Clause as a mere challenge, attempting to work around them by fashioning an order that includes enough of the "right" to avoid judicial review while still maintaining the original discriminatory purpose. The statements in Trump are no different than those which have caused the Court to apply heightened scrutiny in other cases, like Masterpiece. Under the Court's traditional Free Exercise analysis, which is applied in Masterpiece, the Trump Proclamation almost certainly would not have been upheld. While the President certainly has more power in the area of immigration, his actions are not beyond all review, and there are many reasons the Court should review such action. The Court should make it clear that the standard applied in Trump is not 
the norm in Establishment Clause cases, or in Free Exercise cases. Instead, cases factually similar to Masterpiece and Trump should be analyzed according to the traditional Free Exercise framework, and Establishment Clause cases should continue to follow the path set out in Lemon, rather than attempting to apply the mix of standards used by the Court in Trump. 